\title{
A REDAÇÃO DOS ARTIGOS 383 E 384 DO CÓDIGO DE PROCESSO PENAL - E DOS ARTIGOS 407 E 408 DO ANTEPROJETO DE REFORMA DO CÓDIGO DE PROCESSO PENAL - SUPEROU O PROBLEMA DA INCONSTITUCIONALIDADE?
}

\section{Luis Gustavo Grandinetti Castanho de Carvalho' Marcelo Elias Naschenweng ${ }^{2}$}

Resumo: O presente escrito busca examinar se a nova redação conferida aos artigos 383 e 384 do Código de Processo Penal - e reproduzida nos Artigos 407 e 408 do Anteprojeto de Reforma do Código de Processo Penal - superou as inconstitucionalidades que a doutrina, ainda que minoritária, vinha apontando. Nesse desiderato, repassa sumariamente os dois institutos envolvidos. Desde os princípios constitucionais que, compaginados, conformam o sistema acusatório e conduzem a divisão de funções, os mesmos institutos são revisitados, com o conseguinte ajustamento reclamado pelo norte Constitucional.

1 Magistrado no Rio de Janeiro. Doutor pela UERJ. Mestre pela PUC-RJ. Coordenador acadêmico do Programa de Pós-Graduação stricto sensu da Universidade Estácio de Sá. E-mail: Igc@centroin.com.br

2 Magistrado em Santa Catarina e Mestre pela Universidade Estácio de Sá. E-mail: marceloelias@tjsc.jus.br 
Palavras-chave: Constituição. Sistema Acusatório. Processo Penal. Divisão de funções. Artigos 383 e 384 do CPP

\section{INTRODUÇÃO: LEITURA CONSTITUCIONAL DAS NORMAS PROCESSUAIS PENAIS}

$\bigcirc$ processo penal mostra-se como campo propício à discussão e ao enfrentamento de questões constitucionais, justamente, como assinala Alberto Binder, por configurar relação jurídica na qual se busca o ponto de convergência entre a aplicação efetiva da coerção penal e o respeito pela dignidade da pessoa humana ${ }^{3}$.

Guerrero Palomares descreve que como o jus puniendi esta atrelado ao Estado, somente este pode exercitá-lo, por seu caráter público. Daí decorre a necessidade do processo penal em razão do interesse público que se põe em evidência ${ }^{4}$. A instrumentalidade do Processo Penal fora apontada por Lopes Jr. indicando-o como caminho necessário para a imposição da pena, mas também lugar de asseguramento dos direitos fundamentais do acusado5. Toma-se, pois, o processo como atividade desenvolvida para que o dever do Estado concernente à apuração de um ilícito e a conseguinte imposição da pena seja levado a cabo com respeito aos direitos fundamentais encerrados na Constituição.

Com efeito, o direito penal ressai como a atividade estatal que mais agudamente infringe a esfera da intimidade do acusado, colocando em xeque uma série de direitos e valores acudidos pela Constituição. Por isso, o processo penal funciona como espaço privilegiado para o entrechoque de normas, cumprindo ao intérprete dar máxima observância - leia-se eficácia - àquelas de conteúdo constitucional.

3 BINDER, Alberto M., Introdução ao Direito Processual Penal, Rio de Janeiro, Lumen Juris, p.14.

4 PALOMARES, Salvador Guerrero, El princípio Acusatório, p.25.

5 LOPES Jr, Aury, Direito Processual Penal e sua Conformidade Constitucional, Rio de Janeiro: Lúmen Juris, Vol I, p. 23 e 28. 
Referindo-se ao sistema português, Mouraz Lopes, em lição que se aproveita, discorre sobre a necessária compatibilização de um código de processo penal formado durante um período ditatorial com um regime constitucional democrático, a suscitar a questão, posta por Figueiredo Dias "nos termos de $<_{\mathrm{O}}$ direito processual penal ser, por excelência, Direito Constitucional aplicado, de sorte que (de acordo com uma conhecidíssima e respeitada imagem) qualquer oscilação verificada ao nível do casco se transmite com força potenciada ao seu mastro principal >”6

Podemos ver, com Figueiredo Dias, que desta precisa noção do processo penal como direito constitucional aplicado decorrem exigências, tais como: a regulamentação legal de qualquer intromissão, no andamento do processo, na esfera dos direitos constitucionalmente assegurados; a observância de que a lei ordinária não elimine o núcleo essencial destes direitos; do controle judicial da atividade dos órgãos do Estado para atendimento das garantias fundamentais. Enfim, o mandamento de que "a aplicação dos preceitos legais se perspective a partir da Constituição e se leve a cabo de acordo com esta”?

A íntima relação entre Processo e Constituição vem sublinhada por Streck, quando pontua que os textos normativosprocessuais "devem ser revistos e reinterpretados em conformidade com os escopos do Estado Democrático de Direito" ${ }^{\text {. }}$

Dessarte, cumpre ao legislador adequar as leis ordinárias aos ditames constitucionais e ao intérprete, desde já, proceder o ajuste do comando normativo de maneira a resguardar a eficácia das normas constitucionais. Nomeadamente, neste estudo, prossegue-se na leitura dos artigos 383 e 384 do CPP em consonância com o sistema acusatório acolhido na Constituição da República.

6 MOURAZ LOPES, A Tutela da imparcialidade endoprocessual no processo penal Português, p. 17.

7 FIGUEIREDO Dias, Jorge, Direito Processual Oenal, Portugal: Ed. Coimbra,p.74.

8 Streck, Hermenêutica em crise, p.255. 


\section{PROCEDIMENTOS DISCIPLINADOS NOS ART. 383 E 384 DO CPP}

Como se sabe, o artigo 383 do Código cogita da emendatio libelli, que permite ao juiz adequar a capitulação do fato, ainda que da nova capitulação decorra a possibilidade de aumento de pena. A emendatio libelli não é outra coisa senão a correção da inicial, para o fim de adequar o fato narrado ao tipo penal previsto na lei. $\mathrm{O}$ fato é o mesmo, absolutamente o mesmo: o juiz limita-se a corrigir a qualificação jurídico-penal. Não exige, nem a nova redação, nem a anterior, a adoção de qualquer outra providência, senão a prolação da sentença com a capitulação jurídica que parecer mais apropriada ao Juiz. Assim sendo, ainda que a nova definição jurídica resulte pena mais grave, não haverá qualquer prejuízo à defesa, segundo a dicção da lei, prestigiada pela doutrina tradicional.

Cumpre observar que a emendatio é perfeitamente possível em segundo grau, com a limitação da proibição da reformatio in pejus, ou reforma para pior, segundo a qual o julgamento do recurso não poderá ser mais desfavorável que a decisão de primeira instância, em relação à impugnação apresentada exclusivamente pelo recorrente, pois, ainda que o tribunal se encontre autorizado a corrigir a capitulação do injusto, da emenda não poderá resultar, em hipótese alguma, aplicação de pena mais grave, em recurso exclusivo da defesa.

Já o artigo 384 cuida da mutatio libelli que versa sobre a alteração da descrição de fato articulado na denúncia (ou queixa em ação subsidiária da pública) originária. Enquanto na emendatio a definição jurídica diz respeito, única e exclusivamente, à classificação dada ao fato (erro quanto ao direito), na mutatio libelli a nova definição será do próprio fato (erro quanto ao fato), não se alterando somente a capitulação jurídica feita na inicial, mas a própria imputação do fato9. Na mutatio, o que ocorre é a impu-

9 Imputação consiste "em atribuir a alguém um fato delituoso". Os seus elementos são: a) descrição de fatos; b) qualificação jurídico-penal dos fatos; c) atribuição dos fatos a alguém (MARQUES, José de Frederico, Elementos de Direito Proces- 
tação da ocorrência de fato novo. A espécie de desclassificação que surge não decorre simplesmente de juízo de adequação do fato à norma, mas sim de uma nova imputação fática.

\section{BREVE RECAPITULAÇÃO DA INCONSTITUCIO- NALIDADE PRESENTE NA REDAÇÃO ANTERIOR}

Antes de procedermos à recapitulação, convém compreender os dois dispositivos historicamente. No regime anterior ao do Código, só era admissível a desclassificação para melhorar a situação do réu, nunca para piorar. ${ }^{10} \mathrm{~A}$ inspiração para o Código de 1941, para os dois dispositivos, veio da Itália, do "Código Rocco", de motivação inequivocamente fascista. ${ }^{11}$

A doutrina e a jurisprudência tradicionais sustentavam a constitucionalidade dos dois artigos. A doutrina mais recente ${ }^{12}$, porém, e antes da reforma, apontava que, quando importarem agravação da pena, os dois dispositivos não podiam ser invocados porque rompiam com os princípios acusatório, da estabilização do processo, do devido processo legal e da ampla defesa, ao possibilitarem duas condutas que não se adequavam ao sistema acusatório: a desclassificação in pejus, acolhendo o que a denúncia não postulara (CPP 383) e a colaboração do juiz com o MP, para incluir na imputação o que o titular exclusivo da ação penal pública não fizera espontaneamente (CPP 384, parágrafo único). Além disso, a utilização dos dois dispositivos importaria em surpresa para a defesa, que se defende, sim, da capitulação feita na postulação. $\mathrm{O}$ princípio do jura novit curia não deveria carrear à defesa o ônus de, ao ler a denúncia, antever, por exer-

sual Penal, vol. II, pg. 236/237). Para Kelsen, porém, imputação é a ligação de um ilícito com sua conseqüência: "Isso, porém, significa que a imputação não consiste noutra coisa senão nesta conexão entre o ilícito e a conseqüência do ilícito" (Teo-

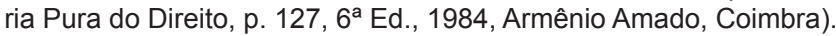

10 ESPÍNOLA FILHO, Eduardo - Código de Processo Penal Brasileiro Anotado, volume I, p. 80, edição histórica, 1980, Ed. Rio

11NASSIF, Aramis - Sentença Penal - O Desvendar de Themis, p. 4, 2005, Ed. Lúmen Júris.

12 Por todos: PRADO, Geraldo - Sistema Acusatório, $3^{\text {a }}$ ed., 2005, Ed. Lumen Júris e BADARÓ, Gustavo Henrique R. Ivahy - Correlação entre acusação e sentença, 2000, RT. 
cício de imaginação e prognose, qual a interpretação do juiz sobre o fato efetivamente narrado. Em outros termos, essa segunda corrente, mais recente e crítica, sustentava que não podia, o juiz, prolatar a sentença sem possibilitar o direito de defesa ao réu, independentemente de a alteração importar em pena mais grave, igual ou menor, pois, do contrário, estar-se-ia condenando o réu por fato do qual não se defendera efetivamente ${ }^{13}$.

\section{A REDAÇÃO CONFERIDA PELA LEI № 11.719, DE 20/06/2008 E ACOLHIDA PELO ANTEPRO- JETO DO CPP}

A nova redação do artigo 383 (Anteprojeto do CPP, art. 407) não representa grande novidade, apenas acrescenta dois parágrafos em que se permite o oferecimento da suspensão condicional do processo e a remessa ao juízo competente se a nova capitulação do fato o reclamar. Permanece, assim, nem comunicada, nem ouvida antes da prolação da sentença.

A nova redação do artigo 384 (Anteprojeto do CPP, art. 408) traz alteração mais significativa. Em primeiro lugar, afasta a iniciativa do Juiz em instar o Ministério Público ou proceder, ele próprio, à nova classificação. Nesse particular, a crítica foi ouvida e afastou-se o Juiz da mutatio libelli. Diante da nova regra, os parágrafos seguintes estabeleceram o controle jurisdicional quanto ao aditamento, ou não aditamento, permitindo-se, ao Juiz: remeter os autos ao Procurador-Geral da Justiça, não receber o aditamento ou recebê-lo, caso em que ficará adstrito à nova capitulação e liberado da originária.

\section{A QUESTÃO DA INCONSTITUCIONALIDADE DOS NOVOS DISPOSITIVOS}

Toda disposição processual penal deve estar concertada com o sistema acusatório constitucionalmente albergado, posto

13 Nesse sentido: TOURINHO FILHO, Fernando da Costa - Processo Penal, volume IV, p. 262/263, $27^{\text {a }}$ ed., Ed. Saraiva, 2005; RANGEL, Paulo - Direito Proces-

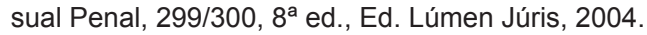


em evidência desde a percepção de que a Constituição da República comete ao Ministério Público a promoção da ação penal (art. 129, I). O princípio acusatório se ajunta aos demais princípios convergentes, verbi gratia, princípio da presunção de inocência, do devido processo legal, do direito ao contraditório e da ampla defesa, da obrigatoriedade, do juízo natural e imparcial, enfim, da dignidade da pessoa humana, de maneira a conformar um sistema onde a imparcialidade do juiz ressumbra como nota marcante. Nessa linha, fica compaginado o sistema acusatório, divisando as funções de acusar, defender e decidir em três pessoas, em três misteres. Na feliz síntese e Mouraz Lopes: "Tão simples (e tão profundo) como isto: a entidade que julga não deve ter funções de investigação e acusação, por um lado - dimensão orgânica - devendo o juiz mover-se dentro dos limites postos pela acusação, por outro - dimensão material” ${ }^{14}$.

Mas em que consiste a acusação? A acusação consiste no trazimento dos fatos a juízo. Figueiredo Dias ${ }^{15}$ anota que o objeto da acusação coincide com o objeto do processo penal e consiste no recorte fático, destacado do comportamento de um sujeito, com repercussão no campo jurídico-penal. Como faz ver Alicia Navarro ${ }^{16}$, a delimitação do objeto terá reflexo no âmbito do mesmo processo - no que tange ao princípio da congruência entre acusação e sentença - e na relação deste com outros processos - litispendência e coisa julgada. Alberto Binder ${ }^{17}$ menciona o caráter intangível do objeto do julgamento a cumprir função garantidora de evitar acusações de surpresa e permitir defesa adequada.

É bem certo que são os fatos e não a capitulação que emprestam contorno ao objeto do processo, mesmo porque, aduz Navarro, o órgão jurisdicional está sujeito ao dever de cognição exauriente, ou melhor, dever de exaustividade, segundo o qual o tribunal deverá examinar o fato que se apre-

14 Mouraz Lopes, José Antonio, A tutela da imparcialidade Endoprocessual no processo penal Português, Portugal: Ed. Coimbra, p.44.

15 Direito Processual Penal, 2004.

16 Acusacion y defensa en el proceso penal,Bosch, 2004. p. 50.

17 BINDER, Introdução ao Direito Processual Penal, p.190.

REVISTA DA ESMESC, v. 17, n. 23, 2010 
senta para a decisão "desde todos os pontos de vista jurídicos" possíveis. Nessa trilha Julio Maier escreve que o tribunal pode adjudicar ao fato uma qualificação jurídica distinta da expressada na acusação (iura novit curia). Conclui que o importante "é o acontecimento histórico imputado, como situação de vida já sucedida (ação ou omissão) que se põe a cargo de alguém como protagonista, do qual a sentença não se pode apartar porque sua missão é precisamente decidir sobre ele" ${ }^{18}$.

Como assinala Cordero, a acusação está entre a norma penal e a condenação. A acusação, olhos postos na figura da tipologia penal, descreve a figura histórica (figura típica) que serve de modelo para a decisão ${ }^{19}$.

Em suma, toca à acusação o trazimento dos fatos a juízo, delimitando o objeto do processo ${ }^{20}$, e nisto consiste o princípio acusatório a reclamar observância da missão atribuída a cada um dos sujeitos que desfilam pela relação processual.

Goldschmidt também prefere que o objeto da coisa julgada se refira ao "fato justiçável" e não a sua qualificação, porque melhor atende aos interesses do acusado que assim não "se vê exposto à mercê de um novo processo pelo mesmo fato" ${ }^{21}$. Fosse a capitulação que fixasse os contornos do processo, depois de absolvido o acusado poderia ele ser processado pelos mesmos fatos sob nova etiqueta penal.

A denúncia consta como peça técnica que deve observar requisitos mínimos para que o réu possa tomar ciência da imputação que lhe fora dirigida e, conseguintemente, produzir sua defesa na amplitude constitucionalmente assegurada. Justamente para dar ao acusado condições de apresentar defesa em simetria

18 MAIER, Julio, Derecho Procesal Penal, Buenos Aires: Ed. Del Puerto, p. 569. 19 CORDERO, Procedimento Penal, p. 379/380.

20 "A acusação determina a amplitude e conteúdo da prestação jurisdicional, pelo que o juiz criminal não pode decidir além e fora do pedido com que o órgão da acusação deduz a pretensão punitiva. Os fatos descritos na denuncia ou queixa delimitam o campo de atuação do poder jurisdicional" (MARQUES, José Frederico - Elementos de Direito Processual Penal, volume I, p. 181, Ed. Bookseller, 1997).

21 GOLDSCHIMIDT, James, Princípios Gerais do Processo Penal, p. 46. 
com a acusação apresentada é que o sistema processual prevê mecanismos de ajustamento da pretensão acusatória de maneira a facultar ao réu, sem assombros ou surpresas, a formação de argumentos e recolhimento de elementos de prova consentâneos com o foco adotado na ação penal. Como retro evidenciado, são os fatos que fixam o contorno da acusação. Tal raciocínio leva a conclusão de que em se verificando no curso do processo que o fato narrado comporta outra qualificação, duas as soluções possíveis: a) viável à acusação adequar a reprimenda, pelo aditamento, com diligências decorrentes dos direitos de defesa; b) viável ao juízo atribuir ao fato outra capitulação, oportunizando as partes manifestação e eventual produção de provas. Por certo descabe ao juízo, sob o signo da imparcialidade, delimitar o âmbito da acusação, sob pena de converter-se em acusador, entrementes o ajustamento da capitulação não significa alterar os contornos da acusação, porque os marcos estão fixados pelos fatos. Em não havendo aditamento por parte do acusador e chegando o processo maduro para julgamento com disparate entre os fatos descritos e a capitulação, não poderia o magistrado num mesmo ato modificar a capitulação e proferir julgamento, ante o inegável prejuízo para a defesa que não pudera se manifestar sobre a nova capitulação. Não obstante, muitos doutrinadores não viam na antiga disposição do art. 383 do CPP qualquer dano à defesa ou afronta ao sistema constitucional, norte que restou acolhido pelo STF, como se depreende do seguinte julgado:

A nova tipificação emprestada pelo juízo, em face da instrução processual, não constitui cerceamento de defesa ou oblívio ao devido processo legal, porquanto o acusado se defende dos fatos narrados na denúncia e não do delito nela qualificado. Hipótese em que a falta de intimação do acusado, em face da desclassificação do delito, não configura cerceamento de defesa. ${ }^{22}$

22 STF, HC 73389/SP, rel. Min. Maurício Corrêa, j. em 30.04.1996; 
Ainda que se concorde com o princípio iura novit curia e com a lição de eméritos doutrinadores que sustentam que o réu se defende dos fatos, uma deferência à defesa há que ser observada. Inapelável que a classificação jurídica importa para a realização plena da defesa, que supõe o conhecimento exato da acusação e a oportunidade de resistir-lhe. Na esteira deste raciocínio a regra de que o acusado se defende apenas dos fatos narrados na denúncia não pode ser acolhida em sua integralidade, pois amplia demais o leque acusatório, em inapartável prejuízo à defesa que pode ser surpreendida por um novo enfoque albergado pelo julgador dissonante do postulado pela acusação. E, nos estritos termos do art. 383 do CPP, sem oportunidade de manifestação. Em razão do princípio da correlação entre sentença e pedido imperativo que, no caso da emendatio, o Ministério Público adite o pedido, oportunizando-se manifestação da defesa quanto ao aditamento ${ }^{23}$, ou, pelo menos, comunicando-se à defesa sobre a possibilidade de nova classificação que importe pena mais grave e abrindo-se, sobre isso, a possibilidade de contraditório. Geraldo Prado ressalva que mais se ajusta ao princípio acusatório a alteração da qualificação jurídica apenas pelo autor, entrementes, aceita a medida levada a cabo pelo juízo dês que: a) o fato venha descrito na acusação inicial com todas as circunstâncias; b) que à defesa se dê oportunidade de debate e eventual produção de provas ${ }^{24}$. Assim, inafastável que o ajuste se dê em decisão anterior à emissão de sentença. Aqui cabível a interpretação conforme para que a leitura do dispositivo se ajuste ao comando constitucional que contempla o sistema acusatório e princípios como a ampla defesa e o do contraditório, desrespeitados quando a alteração é procedida e incontinenti proferida a sentença, sem oportunidade de manifestação das partes quanto ao ajuste do tipo penal provocado pelo juízo. Conforme a argumentação supra, a dili-

23 CARVALHO, Luis Gustavo Grandinetti Castanho de, Processo Penal e Constituição, p. 154.

24 PRADO, Sistema acusatório, p. 150. 
gência concernente à comunicação das partes sobre a alteração procedida, antes da sentença, atende ao sistema acusatório na maneira encampada pela Constituição. Tanto que, o Projeto de Lei para alteração do Código de Processo Penal, emprestava ao art. 383 a seguinte redação:

Art. 383. O juiz, sem modificar a descrição do fato contida na denúncia ou queixa, poderá atribuir-lhe definição jurídica diversa, ainda que, em conseqüencia, tenha de aplicar pena mais grave. $\S 1^{\circ}$ As partes, todavia,deverão ser intimadas da nova definição jurídica do fato antes de prolatada a sentença. $\S 2^{\circ} \mathrm{A}$ providência prevista no caput deste artigo poderá ser adotada pelo juiz no recebimento da denúncia ou queixa. $\S 3^{\circ}$. omissis. $\S$ $4^{\circ}$ omissis

Não obstante, o projeto encaminhado para a sanção recebeu modificação considerável, redundando na mencionada lei $n$. 11.719 de 20 de junho de 2008, que entendeu por suprimir os dois primeiros parágrafos (re)conduzindo o texto legal ao malfadado estágio inicial e à já apontada inconstitucionalidade. Repisese, pelo mecanismo da interpretação conforme, possível enxertar no dispositivo diligência para a cientificação das partes, bastante para redirecionar o processo aos parâmetros constitucionais.

Bem de ver que o artigo 383, e seus $\$ \S$, vem transladado em sua literalidade para o art. 407 do Anteprojeto de Reforma do Código de Processo Penal, remanescendo, pois, a insuficiência legal.

Impõe-se, assim, conduzir o novo artigo 383 do Código ao parâmetro constitucional pelo mecanismo da interpretação conforme à Constituição, sendo obrigatório oportunizar-se às partes a faculdade de se manifestarem, diante da possibilidade de nova classificação da denúncia ou da queixa.

E quais as hipóteses que permitiriam a emendatio? O artigo 383 do Código alberga duas hipóteses diferentes. A primeira: quando houver erro de classificação. $\mathrm{O}$ fato foi explicitamente 
narrado, mas capitulado erroneamente. A segunda: o fato está implicitamente contido na infração capitulada. A primeira hipótese é bastante simples: narra-se um furto e classifica-se como apropriação indébita, por exemplo. Na segunda hipótese, porém, surge o problema de quando se pode considerar presente a implicitude. A doutrina assinala que a implicitude ocorre:

a) quando se trata de uma modalidade privilegiada (causa especial de diminuição de pena) do tipo básico/fundamental;

b) quando o tipo básico/fundamental está contido no tipo agravado (causa especial de aumento de pena);

c) ou quando a definição de um tipo autônomo está contido em outro.

Os exemplos mais recorrentes de implicitude, na doutrina e na jurisprudência, são:

\begin{tabular}{|l|l|}
\hline Tipo desclassificado (implícito) & Em relação ao tipo denunciado \\
\hline Tipos fundamentais/básicos & Tipos qualificados \\
\hline Tipos tentados & Tipos consumados \\
\hline $\begin{array}{l}\text { Tipos privilegiados (homicídio e } \\
\text { lesão privilegiaprivilegiados, furto } \\
\text { de pequeno valor) }\end{array}$ & Tipos fundamentais/básicos \\
\hline Furto & Roubo \\
\hline Desobediência & Resistência \\
\hline Vias de fato & Lesões corporais \\
\hline Lesão leve & Lesão grave \\
\hline $\begin{array}{l}\text { Posse irregular de arma de fogo de } \\
\text { uso us uso permitido (art. 12 da Lei } \\
\text { 10.826/210.826/2003) }\end{array}$ & $\begin{array}{l}\text { Porte ilegal de arma de fogo } \\
\text { de uso permitido (art. 14 da L. } \\
10.826 / 2003)\end{array}$ \\
\hline $\begin{array}{l}\text { Exercício arbitrário das próprias } \\
\text { razões rrazões (CP } 345)^{23}\end{array}$ & Furto \\
\hline
\end{tabular}

23 TJRJ, $5^{\text {a }}$ Câmara, apelação $n^{\circ}$ 3466/2005, embora declarando a extinção da punibilidade pela ausência de queixa-crime. 


\begin{tabular}{|l|l|}
\hline Falsa identidade (CP 307) & $\begin{array}{l}\text { Falsificação de documento público } \\
\text { (CP 297) }\end{array}$ \\
\hline Importunação ao pudor (LCP 61) & $\begin{array}{l}\text { Atentado violento ao pudor com } \\
\text { violência presumida (CP 214 c/c } \\
224, \text { a })^{24}\end{array}$ \\
\hline $\begin{array}{l}\text { Apropriação de coisa achada (CP } \\
\text { 169, parágrafo único, II) }\end{array}$ & $\begin{array}{l}\text { Receptação qualificada (CP 180, } \\
\left.\S 1^{\circ}\right)\end{array}$ \\
\hline
\end{tabular}

Nos casos acima e em muitos outros, o juiz poderá atribuir classificação diversa. Deve, porém, como sustentado aqui, avisar as partes sobre essa possibilidade, para que tenham oportunidade de se manifestarem (e o réu de se defender da nova classificação).

Já com relação ao artigo 384 do Código, na hipótese de surgirem fatos novos, que importem alteração da capitulação jurídica, é essencial que o Ministério Público adite a denúncia, qualquer que seja a conseqüência do aditamento: seja para agravar ou não a pena. Veja-se: fatos novos, tanto que o artigo em comento assim principia "Encerrada a instrução probatória (...)”, por lógico, é no andar da instrução probatória que poderá advir fato inédito e suficiente - leia-se, importante -, apto a interferir na capitulação originária.

A antiga redação, dificultosa, trazia "circunstância elementar”. Circunstância advém do latim circumstantia que significa conservar-se ou estar ao redor, por corolário de lógica, não pode residir ao centro, como parte integrante ou constituinte de um todo. Ou se coloca ao derredor ou compõe o núcleo. Em lugar da expressão "circunstância elementar não contida, explícita ou implicitamente”, o novo dispositivo apenas disse "elemento ou circunstância da infração penal não contida na acusação”. A compreensão das duas expressões é a mesma da apontada pela doutrina ${ }^{25}$ : não só uma entidade jurídica diversa

24 TJRJ, $7^{\text {a }}$ Câmara, emb. inf $n^{0}$ 174/2005, Des. Maria Zélia.

25 "Circunstância, portanto, que entra na constituição do crime e difere substancialmente das circunstâncias qualificativas e gradativas" (ESPÍNOLA FILHO, Eduardo - Código de Processo Penal Brasileiro Anotado, volume I, p. 88, edição histórica, Ed. Rio, 1980. 
da capitulada na peça acusatória, mas também a transformação do tipo fundamental em modalidade especial.

Dessarte, o aditamento também é cabível no caso de surgimento de fato, no decorrer da instrução penal, com repercussão na acusação: ampliação do âmbito fático da acusação. Todavia, vedado ao magistrado acrescer à descrição contida na peça inaugural fatos revelados no transcorrer da instrução, como queria o antigo art. 384, caput, do CPP, por violar diretamente o princípio acusatório, vez que a acusação reside justamente no trazimento dos fatos apontados contra o acusado. Igualmente descompassada a providência do parágrafo único do mesmo artigo (antiga redação) para que o juízo provoque o órgão ministerial visando ao aditamento da denúncia. Não toca ao julgador instar parte alguma para que adite novos fatos, independentemente da quantidade de pena imposta. O aditamento acerca de novos fatos não descritos na denúncia não pode proceder nem decorrer direta ou indiretamente, por acréscimo ou instigação - de ato do julgador, mas sim de iniciativa livre da acusação. Nessa linha, o surgimento de novos fatos deve ser percebido e apontado unicamente pela acusação e não pelo juízo, pois neste último caso haveria violação direta ao princípio acusatório. No mesmo raciocínio Paulo Cláudio Tovo escreve que "em qualquer das hipóteses do art. 384 e seu parágrafo único, portanto, sempre é necessário o aditamento, sob pena de admitirmos que o juiz também possa ser acusador, acusador e juiz ao mesmo tempo" ${ }^{26}$. O projeto de lei, retro citado, que objetivava modificar dispositivos do CPP, também propôs uma alteração substancial da redação do artigo, porque não mais encarrega o juiz de proceder ou instar a alteração fática, tratando o procedimento como mero aditamento pelo Ministério Público, senão vejamos:

Art. 384. Encerrada a instrução probatória, se entender cabível nova definição jurídica do fato, em conseqüência de prova existente nos autos de elemento ou circunstância da infração penal não

26TOVO, Paulo Cláudio, Introdução à principiologia do Processo Penal Brasileiro, in Estudos de Direito Processual Penal, livraria do advogado, p. 31. 
contida na acusação, o Ministério Público poderá aditar a denúncia ou queixa, se em virtude desta houver sido instaurado o processo em crime de ação pública, reduzindo-se a termo o aditamento, quando feito oralmente. $\S 1^{\circ}$ Ouvido o defensor do acusado e admitido o aditamento o juiz, a requerimento de qualquer das partes, designará dia e hora para a continuação da audiência, com inquirição de testemunhas, novo interrogatório do acusado, realização de debates e julgamento. $\S$ $2^{\circ}$ omissis. $\S 3^{\circ}$ Havendo aditamento, cada parte poderá arrolar até três testemunhas, no prazo de três dias. $\S 4^{\circ}$ omissis.

De acordo com o retro explanado, a modificação contida no projeto observa o princípio acusatório, afastando o juiz do trazimento dos fatos a julgamento. Contudo, insta considerar que na oportunidade de sua conversão em lei (n. 11.719), em 20 de junho de 2008, introduziu-se no artigo supratranscrito um parágrafo que consigna: "Não procedendo o órgão do Ministério Público ao aditamento, aplica-se o art. 28 deste Código" ( $\$ 1^{\circ}$ ).

Inescondível o retrocesso operado com a inserção da regra fiscalizadora à carreação dos fatos a serem submetidos a juízo, em atropelo ao princípio acusatório.

A providência do art. 28 do CPP é desaconselhável porque em desarmonia com a ciência processual moderna que distingue a função imparcial do Juiz da função parcial do Promotor. Assim, a remessa dos autos ao Procurador-Geral consta como fiscalização do exercício da ação penal, atribuição que não encontra amparo em sistema que aspira pela imparcialidade do julgador no seio de um processo penal democrático ${ }^{27}$.

O desajuste com o sistema acusatório se evidencia, tanto que o Anteprojeto de Reforma do Código de Processo Penal cuidou de expurgar a fiscalização anômala exercida pelo juízo em face da acusação, suprimindo, pois, o parágrafo respectivo.

27 CARVALHO, L.G Grandinetti Castanho de, Lei dos Juizados Especiais Criminais, Rio de Janeiro: Lúmen Júris, p. 78. 
Voltando-se a atual redação do art. 384 é de se notar que quando da conversão do projeto em lei outra alteração foi levada a efeito em desalinho com o sistema constitucionalmente adotado. O penúltimo parágrafo (na lei convolado em $\S 4^{\circ}$ ) além de cuidar do número de testemunhas, acresceu que o juiz na sentença ficará adstrito aos termos do aditamento. Concessa venia, em observância ao princípio da obrigatoriedade o aditamento não importa na minoração ou no abandono do pedido originário, mas sim na sua alteração pela adição do novo fato, como se de denúncia alternativa se tratasse. Vale notar a lição de Silva Jardim, ao lembrar que o STF decidiu que o aditamento realizado não importa no desfazimento da imputação originária. Nessa linha, escreve que "mesmo que o Ministério Público adite a peça acusatória vestibular para nela incluir fato penalmente relevante que altere a tipicidade, não fica o magistrado impedido de condenar o réu pelo fato imputado anteriormente"28, remetendo ao seguinte julgado:

Exegese do art. 384, parágrafo único, do CPP. Nessa hipótese, não fica o juiz impedido de manter a primitiva definição da denúncia. $O$ que a lei não quer e é que venha o réu a ser condenado por fato do qual não haja tido oportunidade para se defen$\operatorname{der}^{29}$.

Conclui o doutrinador, com acerto, que procedido o aditamento, ao juiz caberá apreciar tanto a conduta imputada na denúncia como aquela atribuída no aditamento, cuidandose de imputação alternativa superveniente, reputando plausível tal providência ${ }^{30}$. Efetivamente, procedido o aditamento pela iniciativa da acusação, a imputação alternativa se mostra concertada com o sistema acusatório ${ }^{31}$.

28 SILVA JARDIM, Direito Processual Penal, p. 154.

29 STF, RHC, 59837/RJ, Min Néri da Silveira, j. em 27.04.1982.

30 SILVA Jardim, op. cit. p. 154.

31 Como descreve Silva Jardim, não há prejuízo para a defesa. "Na imputação alternativa a acusação penal é determinada e os fatos são atribuídos aos réus de forma concreta, descritas todas as suas circunstâncias, como quer o art. 41 do Código de 
De outra banda, a subtração da imputação originária como pretende a nova redação dada ao artigo $384, \$ 4^{\circ}$, infringe o princípio da indisponibilidade da ação penal.

Neste passo, impende abrir parêntesis e descer à análise do principio da obrigatoriedade, segundo o qual o processo e seu objeto não estão subordinados ao poder de disposição dos sujeitos processuais, pondo em evidência o interesse público que rege a atividade processual penal. Em nosso sistema descabe arbitrariedade, de modo que o juízo de conveniência da não propositura ou não seguimento da ação penal, deve vir regrado pela leitura Constitucional dos dispositivos legais. O interesse público em jogo faz ver que o objeto do processo penal não se afigura como desimportante e não está entregue ao talante das partes.

A divisão dos sujeitos da relação processual e a delimitação das atribuições respectivas, aliadas aos princípios constitucionais referentes, ante o interesse público em jogo, conduzem a observância da noção constitucional do princípio acusatório formal, de maneira que a aplicação do direito penal não desatenda aos direitos fundamentais conquistados ao longo do tempo, garantindo a convivência do dever punitivo no Estado com o sagrado ideário de dignidade que se liga à natureza humana.

A atuação processual penal - e, igualmente, penal - vem cercada por uma série de princípios a acompanhar os passos despendidos desde o início da investigação até a aplicação da pena. Por interferir gravemente na esfera de intimidade do

Processo Penal. Vale dizer, o réu sabe perfeitamente de que condutas está sendo acusado e delas pode amplamente se defender; apenas se amplia o thema decindendum, ao qual estará sempre vinculada a prestação jurisdicional, daí porque os limites da coisa julgada ficarão ampliados". (Ação Penal Pública, Ed. Forense, 2001.p.130). Em igual sentido J. Maier, defende a acusação alternativa ou subsidiária: "ella supone que el acusador pondrá en juego las hipótesis posibles, cuidando de describir todas las circunstancias necesarias para que pudean ser verificadas en la sentencia, sin perjuicio de ordenar el escrito de manera que permita entender cuál es la tesis principal y cuál o cuáles las subsidiarias o alternativas. Una acusación construida de esa forma permite la constestación defensiva, la prueba y la decisión; se observa claramente cómo ella es el pilar fundamental que permite el ejercicio idóneo del derecho de defensa". (Derecho Procesal Penal, 574) 
cidadão, alheando direitos a ele muito caros, só se justifica quando imprescindível para a preservação do bem jurídico protegido: daí a pertinência da mínima intervenção do direito penal, que funciona como ultima ratio, como soldado de reserva, em razão do princípio da subsidiariedade. Nesse viés, o processo penal - e seu objeto - não pode ter sua importância apoucada e entregue à vontade das partes, como matéria disponível e destituída de interesse para o Estado que se pretende Democrático de Direito. Assim, guarda-se harmonia com a independência da função acusatória ao tempo em que se evita o exercício discriminatório da persecução criminal.

Concluindo, o exame do artigo, com a redação trazida pela Lei n. 11.719/08, reclama interpretação conforme a Constituição, de maneira a apartar: a) a indevida remessa dos autos ao Procurador-Geral $\left(\S 1^{\circ}\right)$, por violação ao princípio acusatório; e b) a censurável adstrição do juiz aos termos do aditamento $\left(\$ 4^{\circ}\right.$, parte final), por desatender a indisponibilidade da ação penal.

Calha lembrar que apenas se permite a mutatio na ação de iniciativa pública ou na de iniciativa privada subsidiária da pública. Segundo o Antreprojeto de Reforma do Código de Processo Penal a ação penal privada não terá mais lugar no sistema processual penal brasileiro, salvante a hipótese subsidiária, com assento constitucional. O Anteprojeto supracitado, trouxe para o seu artigo 408 a redação disposta no art. 384 do CPP, dela apenas excluindo o parágrafo respeitante ao encaminhamento dos autos para o Procurador-Geral $\left(\$ 1^{\circ}\right)$.

Conforme Rangel, há dois tipos de aditamento: a) o próprio e b) o impróprio. a) $\mathrm{O}$ próprio pode ser real ou pessoal, conforme sejam acrescentados fatos (real) ou acusados (pessoal) cuja existência era desconhecida quando do oferecimento da denúncia. b) $\mathrm{O}$ aditamento impróprio não se acresce fato novo ou sujeito, mas corrige-se alguma falha na denúncia, retificando-se dados relativos ao fato ${ }^{32}$.

32 RANGEL, Paulo, Direito Processual Penal, Rio de Janeiro: Lúmen Júris, 2007 
O aditamento convém em razão da conexão e continência, para conduzir a um julgamento único e evitar decisões conflitantes, sem contar a economia processual evidenciada e o melhor aproveitamento da instrução.

Passemos aos exemplos da doutrina e da jurisprudência de elementos não contidos na denúncia e que impõem a aplicação do CPP 384 e, conseqüentemente, o aditamento:

\begin{tabular}{|l|l|}
\hline Crime culposo e vice-versa & Crime doloso e vice-versa ${ }^{33}$ \\
\hline Estelionato (CP 171) & Exploração de prestígio (CP 357) $)^{34}$ \\
\hline $\begin{array}{l}\text { Corrupção passiva (CP 317) e usur- } \\
\text { pação de função pública (CP 328) }\end{array}$ & Falsidade ideológica (CP 299) $)^{34}$ \\
\hline $\begin{array}{l}\text { Tráfico de influência com causa } \\
\text { especial de aumento de pena (CP } \\
332 \text { p. único) }\end{array}$ & Corrupção ativa (CP 333) 34 \\
\hline Estelionato (CP 171) & $\begin{array}{l}\text { Falsificação de documento } \\
\text { público (CP 297) }\end{array}$ \\
\hline Furto (CP 155) & Receptação ${ }^{34}$ (CP 180) \\
\hline Furto (CP 155) & Apropriação indébita (CP 168) \\
\hline
\end{tabular}

Em todos esses casos, e em muitos outros, é indispensável o aditamento, dando-se oportunidade à defesa, nos termos do parágrafo 2, do artigo 384, do Código.

Tocante ao procedimento, o aditamento poderá ser feito oralmente, ao final da audiência onde foi colhida a nova prova, reduzido a termo. É possível também que o aditamento seja procedido em até cinco dias, após a audiência, se houver requerimento pela acusação. Apresentado o aditamento, impende ouvir o defensor em cinco dias. Acolhido o aditamento, as

33 ESPÍNOLA FILHO, Eduardo - Código de Processo Penal Anotado, p. 94, $2^{\circ}$ volume, edição histórica, 1980, Editora Rio e TJRJ, $7^{\text {a }}$ Câmara, apelação $n^{\circ}$ 2005.050.02036, Des. Eduardo Mayr.

34 Precedente da súmula 453 STF - HC 40.359, 1964.

35 Precedente da súmula 453 STF - Rext. 55.392/MG, 1964.

36 Precedente da súmula 453 STF - HC 40.114/DF, 1963.

37 ESPÍNOLA FILHO, Eduardo - op. cit., p. 110.

38 TJRJ, $7^{\text {a }}$ Câmara, apelação n 2005.050.03391, Des. Eduardo Mayr. 
partes poderão arrolar até três testemunhas. A requerimento de qualquer das partes o magistrado designará audiência em continuação, com inquirição de testemunhas, novo interrogatório, realização de debates e julgamento.

Da decisão que recebe o aditamento não cabe recurso, tal como ocorre na denúncia, remanescendo com via possível a do habeas corpus. Rejeitado o aditamento, aplica-se por analogia o art. 395 (que cuida da rejeição da denúncia), ensejando o recurso em sentido estrito $(581, \mathrm{I})$. Se a sentença se der na audiência caberá apelação, conforme art. 593,§ 4o do CPP ${ }^{39}$.

Não promovendo, o Ministério Público, o aditamento, descabe o envio à Chefia do Ministério Público, por inconstitucional a fiscalização da acusação por parte do Juiz, remanescendo como necessário o exame do caso de acordo com o desenho fático apresentado na inicial acusatória.

\section{CONCLUSÃo}

Reconheça-se o progresso operado pela legislação modificadora do Código em demarcar com mais precisão as funções dos sujeitos processuais, preservando a imparcialidade do Juiz e atribuindo ao Ministério Público o dever de aditar a denúncia para modificar sua narrativa fática (CPP, art. 384), nada obstante as dissonâncias já enfrentadas, havidas nos parágrafos do sobredito artigo (precisamente nos $\S \S 1^{\circ}$ e $4^{\circ}$ ).

Ainda, faltou, à reforma, melhor resguardar a defesa, obrigando o Juiz a incluir diligência com vistas a manifestação das partes, quando proceder a correção da qualificação jurídica deduzida na inicial acusatória (CPP, art. 383).

Abstract: Abstract: This paper examines if the recent amendments on articles 383 and 384 of the Brazilian Code of Criminal Procedure (Código

39 Mendonça, Andrey Borges de, Nova Reforma do Código de Processo Penal, ed. Método, 2008,p.236. 
de Processo Penal), which are reproduced on the articles 407 and 408 of the new Code of Criminal Procedures, have overcome the unconstitutionalities some law scholars. To achieve this goal the author reviews briefly both institutions, starting with their analysis under the constitutional principles that define the adversary system and lead to the parties' different functions that characterize this system. With this analysis both institutions are reviewed in such a way to harmonize them is such a way to hamornize them with the Brazilian constitutional principles.

Keywords: Constitution - Adversary System Criminal Procedures - Division of functions - Articles 383 and 384 of the Brazilian Code of Criminal Procedure (Código de Processo Penal).

\section{REFERÊNCIAS}

BINDER, Alberto M., Introdução ao Direito Processual Penal, Rio de Janeiro: Lúmen Iuris, 2003.

CORDERO, Franco, Procedimentto Penal, I, 2000.

FIGUEIREDO DIAS, Jorge, Direito Processual Penal, Portugal: Ed. Coimbra, 2004.

GOLDSCHMIDT, James, Princípios Gerais do Processo Penal, Belo Horizonte: Líder, 2002.

GRANDINETTI CASTANHO DE CARVALHO, Luis Gustavo, Processo Penal e Constituição, Rio de Janeiro, Lúmen Iuris: 2006. . e PRADO, Geraldo, Lei dos Juizados Especiais Criminais Rio de Janeiro: Lúmen Júris, 2006.

KELSEN, Teoria Pura do Direito, São Paulo: Martins Fontes, 2000.

LOPES JÚNIOR, Aury, Direito Processual Pena e sua Conformidade Constitucional, Vol I, Rio de Janeiro: Lúmen Júris, 2007.

MAIER, Julio B. J., Derecho Procesal Penal, Buenos Aires: Ed. Del Puerto, 2004. 
MARQUES, José Frederico, Elementos de Direito Processual Penal, Campinas/ SP: Millennium, 2003.

MENDONÇA, Andrey Borges, Nova Reforma do Código de Processo Penal, Ed. Método, 2008.

MOURAZ LOPES, José Antônio, A tutela da imparcialidade endoprocessual no processo penal português, Portugal: Coimbra Editora, 2005.

NASSIF, Aramis, Direito Penal e Processual Penal, uma abordagem critica, Rio de Janeiro: Lúmen Júris, 2002.

NAVARRO, Alicia Gonzáles, Acusacion y defensa en el proceso penal, Barcelona/ ES: Bosch, 2004.

PALOMARES, Salvador Guerrero, El princípio Acusatório, Navarra: Editorial Aranzadi, 2005.

PRADO, Geraldo, Sistema Acusatório, Rio de Janeiro: Lúmen Iuris, 2006.

RANGEL, Paulo, Direito Processual Penal, Rio de Janeiro: Lúmen Júris, 2007.

SILVA JARDIM. Afrânio, Ação Penal Pública, Princípio da Obrigatoriedade. Rio de Janeiro: Editora Forense, 2001. .. Direito Processual Penal, Rio de Janeiro: Editora Forense, 2007.

STRECK, Lenio Luiz, Hermenêutica Jurídica e $(m)$ Crise, Porto Alegre: Livraria do Advogado, , 2005.

TOURINHO FILHO, Fernando da Costa, Processo Penal, Vol I e IV, SP:Saraiva, , 2003.

TOVO, Paulo Cláudio, Introdução à principiologia do Processo Penal Brasileiro, in Estudos de Direito Processual Penal, Porto Alegre: Livraria do advogado, 1995.

WUNDERLICH, Alexandre e CARVALHO, Salo de, organizadores, Novos diálogos sobre os juizados especiais criminais, Rio de Janeiro: Lumes Juris, , 2005. 